\title{
GAYA KEPEMIMPINAN DAN PELAKSANAAN SUPERVISI KEPALA SEKOLAH UNTUK MENINGKATKAN KINERJA GURU
}

\author{
Susanti, Muhammad Imad \\ Universitas Islam Negeri Sunan Gunung Djati Bandung \\ susanti.duo93@gmail.com, Moch.imad7@gmail.com
}

\begin{abstract}
ABSTRAK
Penelitian ini menggambarkan gaya kepemimpinan kepala sekolah, menggambarkan program pengawasan pengajaran, menjelaskan pelaksanaan pengawasan pengajaran, menjelaskan teknik dalam melakukan pengawasan pengajaran, menjelaskan tindak lanjut oleh kepala sekolah, menggambarkan faktor penghambat pengawasan pengajaran. Metode deskriptif dengan pendekatan kualitatif, dilakukan di Sekolah Menengah Al-Muhajirin Purwakarta, diamati oleh kepala sekolah, wakil kepala sekolah dan kolega. Hasil gaya penelitian kepemimpinan kepala sekolah dalam meningkatkan disiplin guru adalah dengan menggunakan gaya kepemimpinan otoriter dan demokratis. Teknik Pengawasan Pengajaran yang digunakan oleh kepala sekolah adalah: Teknik untuk mengawasi individu dengan melakukan dan teknik kelompok dengan kegiatan. Tindak lanjut dari hasil pengawasan oleh Kepala Sekolah: bimbingan berdasarkan hasil kunjungan kelas, program pelatihan guru, peluang untuk berpartisipasi aktif dalam kegiatan MGMP, pelatihan baik oleh pemerintah daerah dan pemerintah pusat atau lembaga lainnya. Hambatan pengawasan: rendahnya kompetensi beberapa pengawas yang ditunjuk, kegiatan di luar jadwal pengawasan, dan sulit untuk mengubah kebiasaan lama.
\end{abstract}

Kata kunci: gaya kepemimpinan, pengawasan, kinerja guru

\section{ABSTRACT}

This study describes the leadership style of principals, describes the teaching supervision program, describes the implementation of teaching supervision, describes the techniques in carrying out supervision of teaching, describes the follow-up by the principal, describes the inhibiting factors of teaching supervision. Descriptive methods with qualitative approaches, carried out in Al-Muhajirin Purwakarta Middle School, observed by the principal, vice-principal and colleagues. The results of the research style of principals' leadership in improving teacher discipline is to use authoritarian and democratic leadership styles. Teaching Supervision techniques used by principals are: Techniques for supervising individuals by doing and group techniques with activities. Follow-up of the results of supervision by the Principal: guidance based on the results of class visits, teacher training programs, opportunities to actively participate in MGMP activities, training both by the local government and the central government or other agencies. Obstacles to supervision: low competence of some appointed supervisors, activities outside the supervision schedule, and difficult to change old habits.

Keywords: leadership style, supervision, teacher performance

\section{PENDAHULUAN}

Dalam upaya menghasilkan
pendidikan yang berkualitas di
sekolah, banyak faktor atau
komponen yang terlibat di dalamnya
baik manusia maupun non manusia.
Sekolah merupakan salah satu

organisasi yang kompleks dan unik, sehingga dalam pelaksanaanya memerlukan koordinasi yang tinggi dengan segala komponennya. Kepala sekolah selaku pemimpin secara langsung merupakan contoh nyata 
dalam aktivitas kerja bawahannya.

Kepala sekolah yang rajin, cermat, peduli terhadap bawahan, akan berbeda dengan kepemimpinan yang acuh tak acuh, kurang komunikatif apalagi arogan dengan komunitas sekolahnya.

Kepala sekolah memiliki peranan yang sangat penting dalam menggerakkan, dan menyerasikan semua sumber daya pendidikan yang tersedia di sekolah dan mempergunakan sesuai kebutuhan. Artinya, kepemimpinan kepala sekolah merupakan salah satu faktor yang dapat mewujudkan visi, misi, tujuan dan sasaran sekolah melalui program-program yang dilaksanakan secara terencana dan bertahap. Kepala sekolah dituntut mempunyai kemampuan manajemen dan kepemimpinan yang memadai agar mampu mengambil inisiatif dan prakarsa untuk meningkatkan mutu pendidikan di sekolah. Mulyasa (2013 [2]:6) mengemukakan bahwa: Manejemen dan kepemimpinan kepala sekolah perlu lebih ditekankan dalam koordinasi, komunikasi, dan supervisi, karena kelemahan dan hambatan pendidikan seringkali bersumber dari kurangnya koordinasi, komunikasi, dan supervisi, sehingga menyebabkan persepsi yang berbeda di antara komponen-komponen pelaksana di lapangan (Kepala Dinas, Pengawas, Kepala Sekolah, dan Guru), serta kurangnya sosialisasi dari kepala sekolah kepada seluruh tenaga kependidikan lainnya. Kepemimpinan kepala sekolah berkaitan dengan berbagai tugas dan fungsi yang harus diembannya dalam mewujudkan sekolah yang efektif, produktif, mandiri, dan akuntabel.

Gaya kepemimpinan merupakan karakteristik seseorang untuk mempengaruhi orang lain atau organisasi, sehingga orang lain mau dan mampu bergerak serta meneladani sikap dan watak pribadinya kearah pencapaian tujuan. Gaya kepemimpinan adalah norma prilaku oleh seseorang pada saat itu mempengaruhi orang lain. Selanjutnya, Wahyudi (2012:123) menyatakan bahwa: Gaya kepemimpinan yang diterapkan pada tingkat kematangan atau kedewasaan (mature) dewasaan bawahan dan tujuan yang ingin dicapai. Bawahan sebagai unsur penting yang terlibat dalam mencapai tujuan mempunyai perbedaan dalam hal kemampuan, kebutuhan dan kepribadian, sehingga pendekatan yang dilakukan pemimpin disesuaikan dengan tingkat kematangan bawahan.

Salah seorang pemimpin yang memiliki salah satu tipe bisa menyesuaikan diri dengan situasi yang dihadapi dalam melaksanakan kepemimpinannya. Menurut Danim (2012:212-214) "ada beberapa tipe kepemimpinan tersebut: 1) pemimpin otokratik, 2) pemimpin demokratik, 3) pemimpin permisif". Pemimpin profesional adalah seorang 
'seniman' dalam memimpin. Seni adalah buah kreasi personal yang mungkin tidak dimiliki orang lain. Oleh karena itu, seni dalam memimpin berbeda pada setiap orang.

Guru merupakan salah satu elemen kunci dalam sistem pendidikan, khususnya di sekolah. Semua komponen lain, mulai dari kurikulum, sarana-prasarana, biaya, dan sebagainya tidak akan banyak berarti apabila esensi pembelajaran yaitu interaksi guru dengan peserta didik tidak berkualitas. Kinerja guru merupakan prestasi kerja atau unjuk kerja yang diperoleh seseorang dalam melaksanakan tugas dan tanggungjawab-nya. Kinerja dan kompetensi guru memikul tanggung jawab utama dalam transformasi orientasi peserta didik dari ketidaktahuan menjadi tahu, dari ketergantungan menjadi mandiri, dari tidak terampil menjadi terampil, dengan metode-metode pembelajaran bukan lagi mempersiapkan peserta didik yang pasif, melainkan peserta didik berpengetahuan yang senantiasa mampu menyerap dan menyesuaikan diri dengan informasi baru dengan berpikir, bertanya, menggali, menciptakan dan mengembangkan cara-cara tertentu dalam memecahkan masalah yang berkaitan dengan kehidupannya.

Sebagai ujung tombak di sekolah untuk mewujudkan tujuan pendidikan nasional adalah guru.
Oleh karena itu guru harus mampu melaksanakan fungsi pendidikan secara optimal untuk mewujudkan generasi yang cerdas berkepribadian, berakhlak mulia, mandiri dan terampil serta berkembang sesuai dengan perkembangan zaman.

Peningkatan kompetensi guru bukan saja melalui pemberian penataran, pelatihan maupun memperoleh kesempatan untuk belajar, namun perlu juga memperhatikan guru dari segi peningkatan disiplin, pemberian motivasi, pemberian bimbingan melalui supervisi, pemberian insentif, gaji yang layak.

Supervisi pendidikan merupakan suatu usaha mengkoordinasi dan membimbing secara kontinu pertumbuhan guruguru di sekolah baik secara individu maupun kelompok. Hakekatnya segenap bantuan yang ditujukan pada perbaikan-perbaikan dan pembinaan aspek pengajaran (Mukhtar, 2009:40).

Rendahnya kinerja guru pada SMP Fullday Al-Muhajirin Purwakarta, diduga kurang tepatnya gaya kepemimpinan kepala sekolah dalam menjalankan tugas kepemimpinannya sehingga menyebabkan peningkatan kinerja guru tidak mencapai sasaran. Gaya kepemimpinan kepala sekolah yang diterapkan pada SMP Fullday AlMuhajirin Purwakarta selama ini adalah gaya militer, dimana guru sering diperintah dan merasa jabatan 
kepala sekolah lebih tinggi dari guru, terkadang juga tidak senang diberi masukan (kritikan). Masih ada beberapa guru yang dijumpai kurang disiplin, terutama pada saat masuk kelas, akibatnya situasi pembelajaran tidak dapat terwujud dengan efektif.

Selain permasalah yang ditemukan diatas, hasil observasi pra penelitian diperoleh bahwa masih ada guru di SMP Fullday Al-Muhajirin Purwakarta kurang berhasil dalam mengajar dikarenakan mereka kurang termotivasi untuk mengajar sehingga berdampak terhadap menurunnya produktivitas/kinerja guru.

Berdasarkan uraian tersebut maka penelitian ini bertujuan untuk 1) Mendeskripsikan gaya kepemimpinan kepalas SMP Fullday Al-Muhajirin Purwakarta dalam meningkatkan kinerja guru, 2) Mendeskripsikan program supervisi pengajaran, 3) Mendeskripsikan Pelaksanaan supervisi pengajaran, 4) Mendeskripsikan teknik-teknik yang digunakan dalam melaksanakan supervisi pengajaran, 5) Mendeskripsikan tindak lanjut yang dilakukan oleh kepala sekolah dalam melaksanakan supervisi pengajaran, 6) Mendeskripsikan faktor-faktor penghambat dalam melaksanakan supervisi pengajaran di SMP Fullday Al-Muhajirin Purwakarta.
KAJIAN PUSTAKA

\section{Kepemimpinan Kepala Sekolah}

Kepemimpinan didefinisikan ke dalam ciri-ciri individual, kebiasan, cara mempengaruhi orang lain, interaksi, kedudukan dalam oragnisasi dan persepsi mengenai pengaruh yang sah dan menggerakan prilaku orang lain serta melakukan. Menurut Wahjosumidjo (2011:17) "Kepemimpinan diterjemahkan ke dalam istilah sifat-sifat, perilaku pribadi, pengaruh terhadap orang lain, pola-pola interaksi, hubungan kerja sama antarperan, kedudukan dari satu jabatan administrasi, dan persepsi dari lain-lain tentang legitimasi pengaruh".

Perlu dibedakan antara tipe dan gaya kepemimpinan. Kepemimpinan seseorang dapat digolongkan ke dalam salah satu tipe dan mungkin setiap tipe bisa memiliki berbagai macam gaya kepemimpinan. Salah seorang pemimpin yang memiliki salah satu tipe bisa menyesuaikan diri dengan situasi yang dihadapi dalam melaksanakan kepemimpinannya. Secara umum, Mukhtar dan Iskandar (2009:85) ada tiga tipe kepemimpinan dalam kehidupan suatu oragnisasi, termasuk organisasi sekolah, yaitu: (a) Tipe Otoriter, (b) Tipe Laissez-faire, dan (c) Tipe Demokratis. Perilaku kepemimpinan yang ditampilkan dalam proses manajerial secara konsisten disebut sebagai gaya (style) kepemimpinan. Gaya kepemimpinan lebih cenderung 
kepada situasi. Gaya kepemimpinan yang dimaksud sebagai cara berperilaku yang khas dari seorang pemimpin terhadap para anggota kelompoknya. Dengan demikian, gaya kepemimpinan adalah cara pemimpin berperilaku secara konsiten terhadap bawahan sebagai anggota kelompoknya. Gaya kepemimpinan pendidikan adalah cara seseorang pemimpin lembaga pendidikan dalam mengatur, mengarahkan, dan membimbing guru-guru agar mereka bekerja sama untuk mencapai tujuan pendidikan. Kepemimpinan pendidikan merupakan posisi yang sangat menuntut kemampuan membaca dan memahami karakter, sifat dan kepribadian guru yang menjadi bawahannya.

Greenfield (Mulyasa 2013 [2] :19) mengemukakan bahwa "Indikator kepala sekolah efektif secara umum dapat diamati dari tiga hal pokok sebagai berikut: 1) komitmen terhadap visi sekolah dalam menjalankan tugas dan fungsinya, 2) menjadikan visi sekolah sebagai pedoman dalam mengelola dan memimpin sekolah, dan 3) senantiasa memfokuskan kegiatannya terhadap pembelajaran dan kinerja guru di kelas".

Kepala sekolah sebagai pemimpin yang baik adalah seorang kepala sekolah yang memiliki karakter atau ciri-ciri khusus yang mencakup kepribadian, keahlian dasar, pengalaman dan pengetahuan profesional, diklat dan ketrampilan profesional, pengetahuan administrasi dan pengawasan. Kemampuan yang harus diwujudkan kepala sekolah sebagai pemimpin dapat dianalisa dari kepribadian, pengetahuan terhadap tenaga kependidikan, visi dan misi sekolah, kemampuan mengambil keputusan dan kemampuan berkomunikasi.

Gaya kepemimpinan kepala sekolah, paling tidak ada empat gaya kepemimpinan yang sering dilakukan kepala sekolah dan dipandang representative terhadap peningkatan kinerja guru, yakni gaya kepemimpinan transaksional, visioner, transformasional dan situasional.

\section{Peran dan Fungsi Kepala Sekolah}

Kepala sekolah merupakan jabatan karir yang diperoleh seseoarng setelah sekian lama menjabat sebagai guru. Seseorang diangkat dan dipercaya menduduki jabatan kepala sekolah harus memenuhi kriteria-kriteria yang disyaratkan untuk jabatan dimaksud. Wahjosumidjo menjelaskan "secara sederhana kepala sekolah dapat didefinisikan sebagai seorang tenaga fungsional guru yang diberi tugas tambahan untuk memimpin suatu lembaga atau sekolah dimana diselenggarakan proses belajar mengajar, atau tempat dimana terjadi interaksi antara guru yang memberi pelajaran dan murid yang menerima pelajaran". 
Kepala sekolah berfungsi sebagai pemimpin pendidikan berarti peningkatan mutu akan berjalan dengan baik apabila guru bersifat terbuka, kreatif dan memiliki semangat kerja yang tinggi. Dalam melaksanakan fungsinya, kinerja seorang kepala sekolah sering dirumuskan sebagai EMASLIM, singkatan dari Educator, Manager, Adminis-trator, Supervisor, Leader, Innovator, Motivator.

\section{Kompetensi Kepala Sekolah}

Kepala sekolah dalam mengelola satuan pendidikan disyaratkan menguasai keterampilan dan kompetensi tertentu yang dapat mendukung pelaksanaan tugasnya. Sahertian

(Wahyudi,2012:28) mengartikan "kompetensi sebagai kemampuan melaksanakan sesuatu yang diperoleh melalui pendidikan dan latihan. Kompetensi diperoleh melalui pendidikan dan latihan dengan standari dan kualitas tertentu sesuai dengan tugas yang akan dilaksanakan". Secara umum tugas dan peran kepala sekolah memiliki lima dimensi komptensi sebagaimana termaktub pada Permendiknas Nomor 13 Tahun 2007, tentang "Standar Kepala Sekolah/ Madrasah, yaitu kompetensi kepribadian, manajerial, kewirausahaan, supervisi, dan kompetensi sosial".

\section{Kinerja Guru}

Kinerja adalah performance atau unjuk kerja. Kinerja merupakan terjemahan dari kata performance (job performance). Smith (Usman 2012:63) menyatakan bahwa "performan atau kinerja merupakan hasil kerja dari suatu proses. Artinya, hasil kerja yang dicapai oleh seseorang pegawai dalam melaksanakan tugas yang dibebankan kepadanya". Kinerja yang baik dapat dipengaruhi oleh kemampuan dan motivasi. Kemampuan merupakan hasil perpaduan antara pendidikan, pelatihan, dan pengalaman. Sedangkan motivasi adalah suatu daya pendorong (driveng force) yang menyebabkan seseorang berbuat atau melakukan sesuatu.

Standar kinerja perlu dirumuskan untuk dijadikan acuan dalam mengadakan perbanding-an terhadap apa yang dicapai dengan apa yang diharapkan, atau kualitas kerja adalah wujud perilaku atau kegiatan yang dilaksanakan dan sesuai dengan harapan dan kebutuhan atau tujuan yang hendak dicapai secara efektif dan efesien.

Indikator-Indikator kinerja guru menurut Rebore (Usman 2012:94) "menyangkut dengan (1) kinerja pembelajaran, (2) kinerja profesional, dan (3) kinerja personal". Berkenaan dengan kepentingan penilaian terhadap kinerja guru, Georgia Departemen of Education telah mengembangkan teacher performance asses-sment instrument yang kemudian dimodifikasi oleh Depdiknas menjadi Alat Penilaian 
Kinerja Guru (APKG). APKG merupakan alat pengukur kemampuan guru dalam bentuk kompetensi yang bersifat generic essentials, maka dalam hal ini APKG hanya mengukur kompetensi yang dimiliki atau dapat diasumsikan oleh guru.

Salah satu faktor utama yang menentukan mutu pendidikan adalah guru. Gurulah yang berada di garda terdepan dalam menciptakan kualitas sumber daya manusia. Guru berhadapan langsung dengan para peserta didik di kelas melalui proses belajar mengajar. Di tangan gurulah dihasilkan peserta didik yang berkualitas, baik secara akademis, skill (keahlian), kematangan emosional, dan moral serta spiritual. Sementara itu, menurut Mulyasa (Kunandar 2009 [3] :42) sedikitnya ada tujuh kesalahan yang sering dilakukan guru dalam pembelajaran, yaitu: “(1) mengambil jalan pintas dalam pembelajaran, (2) menunggu peserta didik berperilaku negatif, (3) menggunakan destructive disipline, (4) mengabai-kan perbedaan peserta didik, (5) merasa paling pandai dan tahu, (6) tidak adil (diskriminatif), dan (7) memaksa hak peserta didik".

Guru merupakan ujung tombak keberhasilan pendidikan dan dianggap sebagai orang yang berperan penting dalam pencapaian tujuan pendidikan yang merupakan percerminan mutu pendidikan. Beberapa faktor yang mempengaruhi kinerja guru yang dapat diungkap, antara lain: (1) Kepribadian; Pengembangan profesi guru; (3) Pembelajaran yang diidentikkan dengan kata "mengajar": (4) Terbinanya hubungan dan komunikasi di dalam lingkungan sekolah; (5) Hubungan mutualisme sekolah dengan masyarakat; (6) kesejahteraan; dan (7) Iklim sekolah.

\section{Program Supervisi Pengajaran}

Saat ini pelaksanaan supervisi tidak lagi untuk mencari kesalahan pada bawahan atau karyawan untuk dilakukan perbaikan sebagaimana yang diharapkan. Karena hal ini tidak akan memberikan motivasi peningkatan kinerja guru.

Supervisi dilakukan untuk memperbaiki dan meningkatkan situasi belajar melalui layanan kegiatan supervisi, karena supervisi adalah usaha untuk memperbaiki situasi belajar mengajar, yaitu sebagai bantuan bagi guru dalam meningkatkan kualitas mengajar untuk membantu peserta didik agar lebih baik dalam belajar (Sagala, 2010:88) Supervisi ini dapat dilakukan oleh kepala sekolah dan pengawas atau guru senior yang ditunjuk.

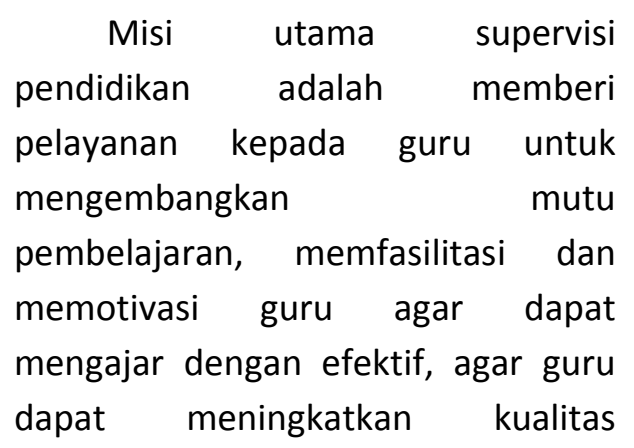


mengajarnya melalui langkahlangkah perencanaan, pelaksanaan serta mengadakan perubahan dengan cara yang rasional.

\section{Pelaksanaan Supervisi Pengajaran}

Supervisi pengajaran dapat dilakukan dengan sistematis melalui tahapan-tahapan sehingga perbaikan yang dilakukan terhadap proses pembelajaran dapat fokus dan rasional. Selain supervisi perorangan maupun kelompok, Pelaksanaan supervisi pengajaran dapat dilakukan dengan supervisi klinis.

Supervisi klinis ini difokuskan pada perbaikan pembelajaran melalui siklus yang sistematis mulai tahap perencanaan, pengamatan dan analisis yang intensif terhadap penampilan pembelajarannya dengan tujuan untuk memperbaiki proses pembelajaran (Mukhtar, 2009:60).

\section{METODE PENELITIAN}

Metode penelitian yang digunakan adalah metode deskriptif dengan menggunakan pendekatan kualitatif untuk mengkaji permasalahan dan memperoleh makna yang lebih mendalam tentang Gaya Kepemimpinan Kepala Sekolah dalam Meningkatkan Kinerja Guru pada pada SMP Fullday Al-Muhajirin Purwakarta.

Lokasi dalam penelitian ini peneliti laksanakan pada SMP Fullday Al-Muhajirin Purwakarta, dengan diobservasikan oleh kepala sekolah, wakil kepala sekolah serta temanteman sejawat. Penelitian ini berlangsung selama satu bulan, yaitu pada bulan Januari sampai pebruari 2019. Sedangkan subjek penelitian ini adalah kepala sekolah dan guru-guru pada SMP Fullday Al-Muhajirin Purwakarta yang yang ditentukan secara acak.

Teknik pengumpulan data dalam penelitian ini ialah melalui wawancara, observasi dan dokumentasi. Selanjutnya, teknik Analisis data terdiri tiga alur kegiatan, yaitu: Reduksi data, Penyajian data dan Penarikan kesimpulan atau verifikasi.

\section{HASIL PENELITIAN DAN \\ PEMBAHASAN}

\section{Hasil Penelitian}

Gaya kepemimpinan kepala sekolah dalam meningkatkan disiplin guru; yaitu kepala sekolah berusahan menjadi teladan di lingkungan sekolah dengan cara datang lebih awal dan pulang paling akhir. Gaya kepemimpinan yang diterapkan kepala sekolah dalam meningkatkan disiplin guru, dari hasil wawancara terungkap bahwa digunakan gaya kepemimpinan memberitahukan (telling), gaya ini dilakukan dengan menemui guru-guru secara personal. Gaya kepemimpinan telling ini dilakukan oleh kepala sekolah pada saat rapat dewan guru, sehubungan dengan gaya telling kepala sekolah setiap pagi, cara yang dilakukan dengan duduk dikantor dewan guru, 
ia memantau setiap guru yang datang dan langsung mengingatkannya bila saat jam mengajar tiba.

\section{Gaya kepemimpinan kepala} sekolah dalam meningkatkan motivasi kerja guru, yaitu kepala sekolah berusaha untuk memotivasi guru dengan menetapkan standar kerja yang tinggi yang berbasis pada peningkatan mutu. Kepala sekolah sangat menyadari dan mengerti bahwa pada hakikatnya guru-guru adalah manusia biasa dan tidak pernah luput dari kesalahan dan juga memberikan perhatian penuh dalam menindaklanjuti keluhan serta harapan yang diharapkan oleh guru untuk menciptakan lembaga sekolah yang berkualitas.

\section{Gaya kepemimpinan kepala} sekolah dalam meningkatkan tanggung jawab guru, yaitu Kepala sekolah juga memberikan penghargaan, dan kesejahteraan lain yang luar dari kesejahteraan yang telah ditetapkan dalam skala nasional. Dengan adanya penghargaan, insentif, dan kesejahteraan tersebut diharapkan dapat menambah kebutuhankebutahan lain yang kian meningkat. kepala sekolah menganut gaya kepemimpinan demokratis dalam meningkatkan tanggung jawab guruguru. Dalam peningkatan tanggung jawab guru, kepala sekolah berusaha mendorong dan meningkatkan mengarahkan guru-guru untuk bekerja baik dalam kegiatan ekstrakurikuler maupun non-ekstrakurikuler.

Kendala-kendala yang dihadapi oleh kepala sekolah dalam meningkatkan kinerja guru, dengan cara mengatur administrasi kelas dan memberlakukan peraturan-peraturan tepat waktu baik dari segi kehadiran maupun ketepatan jadwal mengajar. Selanjutnya kendala-kendala kepala sekolah yang dihadapi kepala sekolah dalam motivasi kerja guru, yaitu melalui kesiapan mental dan fisiknya dalam mengajar. Kepala sekolah selalu mengingat guru-guru agar selalu menjaga kesehatan, baik dirinya sendiri maupun keluarga. Upaya yang dilakukan kepala sekolah dalam meningkatkan motivasi guruguru dengan cara memberi wejengan, semangat, dan teratur menjaga kesahatan, terutama semangat dalam mengajar di kelas.

Kendala yang dihadapi kepala sekolah dalam meningkatkan tanggung jawab guru adalah masih ditemukan guru-guru yang kurang mampu menjabarkan RPP dan silabus dengan benar, sehingga guru-guru tersebut hanya menjalankan tugas mengajar saja tanpa diserta dengan perencanaan yang matang. Upaya yang dilakukan kepala sekolah dalam menyikapi masalah tanggung jawab guru yaitu dengan cara mengadakan pelatihan bagi guru-guru yang belum teratur dalam menjabar RPP dan silabus, bahkan kepala sekolah sering meminta bantuan kepada pengawas atau dinas terkait untuk 
mensosialisasikan guru-guru dalam peningkatan administrasi guru.

\section{Pembahasan gaya kepemimpinan}

Disiplin sekolah merupakan sesuatu hal yang mudah diucapkan, tetapi sukar dilaksanakan; bukan hanya oleh peserta didik, tetapi oleh guru bahkan oleh kepala sekolah. Disiplin adalah suatu keadaan tertib, ketika orang-orang yang tergabung dalam suatu sistem tunduk pada peraturan-peraturan yang ada dengan senang hati. (Mulyasa 2013 [1]:191) mengemukakan "disiplin sekolah dapat diartikan sebagai keadaan tertib, ketika guru, kepala sekolah dan staf, peserta didik yang tergabung dalam sekolah tunduk kepada peraturan yang telah ditetapkan dengan senang hati". Membina disiplin di sekolah perlu dimulai dengan prinsip yang sesuai dengan tujuan pendidikan nasional, yakni sikap demokratis. Sehubungan dengan itu, dalam menentukan peraturan disiplin perlu berpedoman pada hal berikut, yakni dari, oleh dan untuk peserta didik, sedangkan guru tut wuri handayani.

Program supervisi pengajaran oleh Kepala Sekolah

Kepala Sekolah dalam
kedudukannya sebagai supervisor
telah menyusun program supervisi
pengajaran bersama dengan wakil
kepala sekolah, kepala program
keahlian, ketua pengajaran dan guru
secara musyawarah. Supervisi yang bersifat ilmiah adalah: (1) Sitematis, artinya dilaksanakan secara teratur, berencana dan kontinu, (2) Objektif dalam pengertian ada data yang didapat berdasarkan observasi nyata bukan berdasarkan tafsiran pribadi, (3) Menggunakan alat pencatat yang dapat memberikan informasi sebagai umpan balik untuk mengadakan penelitian terhadap proses pembelajaran di kelas (Sahertian, 2008:16).

Program supervisi pengajaran ini berorientasi kepada peningkatan kinerja guru dengan memiliki siklus dengan tahap perencanaan, pengamatan dan analisis intelektual. Supervisi difokuskan pada perbaikan pengajaran dengan menjalankan siklus yang sistematis dari tahap perencanaan, pengamatan, dan analisis intelektual yang intensif terhadap penampilan mengajar guru di kelas.

Program supervisi pengajaran yang disusun oleh kepala sekolah berorientasi pada bimbingan terhadap tugas-tugas guru, seperti penyusunan program pengajaran, penyiapan perangkat pembelajaran (Satuan acuan pelajaran, rencana pembelajaran, alat evaluasi, penyiapan media pembelajaran dan lain-lain). Perencanaan harus dirumuskan secara jelas dan dikerjakan secara profesional (Fattah, 2009:12).

Hasil penelitian menunjukkan bahwa ternyata program pembinaan kemampuan mengajar guru yang 
disusun oleh kepala sekolah belum sesuai dasar fase-fase yang diharapkan. Selain itu juga di dalam program belum tercamtumkan sasaran dan jadwal mengenai pelaksanaan pembinaan tersebut secara terperinci. Sebagaimana Castetter (Purwanto, 2005:79), mengemukakan bahwa untuk pengembangan personil edukatif terdapat beberapa fase yang dilakukan yaitu (1) diangnosa kebutuhan pengembangan personal; (2) rancangan program pengembangan personil; implementasi program pengembangan personil dan ; (4) evaluasi program pengembangan personil.

\section{Pelaksanaan Supervisi Pengajaran Oleh Kepala Sekolah}

Pelaksanaan supervisi pengajaran yang dilakukan di SMP Fullday Al-Muhajirin Purwakarta satu kali dalam satu semester dan ada juga lebih dari satu kali untuk beberapa guru, sehingga dalam pelaksanaan supervisi tersebut belum merata kepada semua guru. Program peningkatan kinerja guru melalui pertemuan guru-guru mata pelajaran dihadiri oleh kepala sekolah namun belum mengundang tim pakar dalam hal nara sumber yang kompeten. Seorang kepala sekolah yang memenuhi fungsinya dengan baik, yaitu fungsi pengarahan (directing), pengkoordinasian (coordinating), dan pengkomunikasian (communicating), apabila dia tidak segan-segan menyelenggarakan pertemuan bersama dalam rapat dewan guru dan staf TU secara rutin (Arikunto, 2004:56).

$$
\text { Pelaksanaan supervisi }
$$

pengajaran tidak dilakukan sendiri oleh kepala sekolah, tetapi juga dibantu oleh para wakil kepala sekolah dan guru-guru senior. Kepala sekolah dapat memberikan wewenang kepada guru senior lain yang betul-betul mampu dan berpengalaman dalam supervisi (Wahyudi, 2009:86). Pemberian wewenang ini bertujuan agar semua guru dapat disupervisi tepat waktu, oleh karena itu guru senior juga dapat ditunjuk sebagai supervisor.

Kegiatan pembinaan dilakukan melalui kegiatan seminar, pertemuan ilmiah, kegiatan kunjungan antar kelas/antar sekolah, kadang-kadang masih juga kepala sekolah melakukan pembinaan secara otoriter sehingga hubungan kepala sekolah dengan guru menjadi tidak dekat.

\section{Teknik Supervisi Pengajaran Oleh Kepala Sekolah}

Berdasarkan hasil penelitian bahwa teknik supervisi pengajaran yang dilakukan oleh kepala sekolah adalah teknik individu, dan teknik kelompok. Secara garis besar cara atau tehnik supervisi dapat digolongkan menjadi dua, yaitu tehnik perseorangan dan teknik kelompok (Purwanto, 2005:120-122). 
Disamping itu juga kepala sekolah melakukan supervisi Klinis Pelaksanaan supervisi klinis yang dilakukan oleh Kepala Sekolah dalam suatu siklus yang terdiri dari tiga tahap berikut :

1. Tahap perencanaan awal.

2. Tahap pelaksanaan observasi.

3. Tahap akhir (diskusi balikan). Kepala Sekolah telah melakukan fungsinya sebagai supervisor dalam rangka peningkatan kinerja guru. Supervisi klinis adalah bentuk supervisi yang difokuskan pada peningkatan mengajar dengan melalui siklus yang sistematik, dalam perencanaan, pengamatan (pelaksanaan) serta analisis yang intensif dan cermat tentang penampilan mengajar guru (Sahertian, 2008:36)

\section{Tindak Lanjut Pembinaan Hasil Supervisi}

Kepala sekolah selalu melakukan pemantauan terhadap kemajuan program pembelajaran di sekolah. Program supervisi selain memerlukan data atau informasi yang objektif, juga harus dilaksanakan secara terencana dan kontinu (Sahertian, 2008:98).

Berdasarkan hasil penelitian ditemukan bahwa kepala sekolah juga melakukan evaluasi pembinaan berdasarkan catatan-catatan pada format kunjungan kelas kepada guru untuk setiap tahunnya, sebagai bahan analisis dan masukan dalam membuat program pembinaan guru pada tahun berikutnya.

Kegiatan tindak lanjut juga dilakukan adalah guru-guru diberi kesempatan untuk ikut secara aktif dalam kegiatan musyawarah guru mata pelajaran (MGMP). Pelatihanpelatihan baik yang dilakukan oleh pemerintah daerah maupun pemerintah pusat atau instansi lainnya.

\section{Hambatan-hambatan}

Dalam

Pelaksanaan Supervisi Oleh Kepala Sekolah

Hambatan-hambatan yang dialami oleh Kepala Sekolah dalam pelaksanaan supervisi di SMP Fullday Al-Muhajirin Purwakarta adalah:

1. Rendahnya kompetensi sebagian supervisor yang ditunjuk

Berdasarkan hasil penelitian yang dieproleh menyatakan bahwa sebagian kompetensi supervisor lemah, maka hal inilah yang menjadi salah satu faktor hambatan dalam pelaksanaan supervisi pengajaran.

Supervisor seharusnya menganalisis kondisi setiap guru yang akan disupervisi secara mendalam, bukan saja dari penampilan luar, melainkan juga mencoba membuka isi hatinya, suasana hati, dan kata hatinya untuk mendapatkan pengetahuan yang dalam tentang guru itu (Slater, 2005:132) ".

Kepala sekolah menunjuk guru senior yang ada sebagai 


$\begin{array}{llr}\begin{array}{l}\text { supervisor } \\ \text { dibutuhkan }\end{array} & \begin{array}{l}\text { bimbingan } \\ \text { Kepala }\end{array} & \text { Sekolah } \\ \text { kekurangan SDM. } & \text { karena }\end{array}$

2. Adanya kegiatan di luar jadwal supervisi yang tidak direncanakan

Program supervisi telah disusun dengan sedemikian rupa, namun dalam pelaksanaannya tidak dapat dilakukan sesuai dengan jadual tersebut dikarenakan adanya kegiatankegiatan diluar rencana sekolah. Hal ini terjadi karena kegiatankegiatan tersebut adalah program yang dilakukan oleh pihak eksternal sekolah seperti pelatihan guru oleh P4TK dan kegiatan rapat-rapat atau pertemuan oleh dinas pendidikan kota, dan pihak lain yang memiliki program peningkatan kompetensi guru seperti; LPMP, GIZ dan lain sebagainya.

3. Sulit Merubah Kebiasaan lama

Penyebabnya adalah sangat berakarnya pola pengelolaan sentralistik sehingga pola-pola lama terbiasa digunakan dan sangat sulit untuk di ubah. Mengubah pola kerja, sikap, dan perilaku kepala sekolah, guru, karyawan, kepala dinas dan segenap jajarannya dan pihak lain yang terkait dari pola yang berparadigma kebergantungan menjadi paradigma kemandirian bukan pekerjaan mudah seperti membalik telapak tangan (Wahyudi, 2009:1).
Upaya Kepala SMP Fullday AIMuhajirin Purwakarta untuk meningkatkan kinerja guru melalui supervisi telah dilakukan dalam rangka mewujudkan peningkatan mutu lulusan dan kegiatan tersebut dilakukan secara terus menerus dan terjadwal.

Dalam menegakkan disiplin sekolah, gaya kepemimpinan kepala sekolah adalah sangat menentukan jalannya roda kepemimpinan sekolah. Ada bermacam-macam gaya yang dapat diterapkan kepala sekolah, tetapi untuk mendisiplinkan guru, staf dan siswa, maka kepala sekolah cocok menerapkan gaya instruktif (telling). Wahyudi (2012:140) menyebutkan: Gaya instruktif diterapkan pada guru yang tidak mampu dan tidak berani memikul tanggung jawab, bila menjalankan tugas membutuhkan penjelasan, pengaturan/ pengarahan dan supervisi secara khusus. Gaya kepemimpinan yang bersifat instruktif (G1) tepat untuk diterapkan pada guru yang tidak mampu dan tidak mau menerima tanggung jawab. Kepala sekolah melaksanakan pengawasan secara ketat, dengan demikian derajat hubungan manusia pada kategori rendah akan tetapi perhatian terhadap organisasi tinggi.

Kepala sekolah banyak memberikan instruksi kepada guru dan melaksanakan pengawasan ketat. Pada gaya instruktif, kepala sekolah lebih dominan dalam memberikan pengarahan tentang 
tugas terhadap guru dan sedikit dalam perilaku hubungan (tugas tinggi dan hubungan rendah). Selain gaya instruktif, kepala sekolah juga menerapkan gaya otoriter guna untuk meningkatkan kedisiplinan guru. Apabila guru-guru tidak mengindahkan arahan dari kepala sekolah, maka baru menerapkan gaya otoriter. Engkoswara dan Kamariah (2011:181) menyatakan "ototiter adalah gaya kepemimpinan yang menekan pada kekuasaan dan kepatuhan anggota secara mutlak".

Motivasi adalah tenaga pendorong atau penarik yang menyebabkan adanya perilaku seseorang ke arah suatu tujuan tertentu. Motivasi kerja berkaitan dengan apa yang diinginkan manusia (tujuan), mengapa ia menginginkan hal tersebut (motif), dan bagaimana ia mencapai tujuan tersebut (proses). Mulyasa (2013 [3]:196) menyatakan: Motivasi merupakan salah satu faktor yang turut menentukan kefektifan dan keberhasilan pembelajaran, karena peserta didik akan belajar dengan sungguh-sungguh apabila memiliki motivasi yang tinggi.

Banyak cara yang dapat
dilakukan guru
membangkitkan motivasi belajar
peserta didik, antara lain melalui
kehangatan dan keantusiasan,
menimbulkan rasa ingin tahu,
mengemukakan ide yang
bertentangan, dan memerhatikan
minat belajar peserta didik.
Sehubungan dengan itu, Howard

(Mulyasa 2013 [3]:200) "seorang guru sebaiknya memiliki rasa ingin tahu, mengapa dan bagaimana anak belajar dan menyesuaikan dirinya dengan kondisi-kondisi belajar dalam lingkungan". Dalam meningkat motivasi guru, kepala sekolah menerapkan gaya kepemimpinan konsultatif (selling). Di dalam penerapan gaya ini, guru tidak mampu melaksanakan tugas secara mandiri tetapi mau mengambil tanggung jawab.

Penerapan gaya konsultatif ini, kepala sekolah masih menunjukkan perilaku mengarahkan tugas-tugas guru dan sering memberikan dorongan dan motivasi terhadap penyelesaian tugas (tugas tinggi dan hubungan tinggi). Selain gaya konsultatif di atas, kepala sekolah juga menerapkan gaya otoriter guna untuk meningkatkan motivasi kerja guru. Guru-guru yang tidak mengerjakan tugas dengan benar maka kepala sekolah akan menerapkan gaya otoriter tersebut. Engkoswara dan Kamariah (2011:181) menyatakan "ototiter adalah gaya kepemimpinan yang menekan pada kekuasaan dan kepatuhan anggota secara mutlak".

Guru merupakan faktor yang sangat dominan dalam pendidikan pada umumnya, karena guru memegang tanggung jawab dalam proses pembelajaran, di mana proses pembelajaran merupakan inti dari proses pendidikan secara keseluruhan. Rusman (2009:325) 
menjelaskan "proses pembelajaran merupakan suatu proses yang mengandung serangkaian perbuatan guru dan siswa atas hubungan timbal balik yang berlangsung dalam situasi edukatif untuk mencapai tujuan tertentu, di mana dalam proses tersebut terkandung multiperan dari guru". Jadi tanggung jawab guru bukan sekedar menstransfer ilmu pengetahuan kepada anak didik. Melainkan, guru juga berkewajiban membentuk watak dan jiwa anak didik yang sebenarnya sangat memerlukan masukan positif dalam bentuk ajaran agama, ideologi, dan lain-lain. Memberikan bimbingan sehingga anak didik memiliki jiwa dan watak yang baik, mampu membedakan mana yang baik dan buruk, mana yang halal dan haram, adalah termasuk tugas guru.

Gaya kepemimpinan kepala sekolah yang cocok diterapkan dalam meningkatkan tanggung jawab guru ini adalah gaya instruktif dan gaya delegatif. Wahyudi (2012:140-141) menyebutkan: Gaya instruktif diterapkan pada guru yang tidak mampu dan tidak berani memikul tanggung jawab, bila menjalankan tugas membutuhkan penjelasan, pengaturan/ pengarahan dan supervisi secara khusus. Kepala sekolah melaksanakan pengawasan secara ketat, dengan demikian derajat hubungan manusia pada kategori rendah akan tetapi perhatian terhadap organisasi tinggi. Dalam gaya delegatif "kepala sekolah sedikit sekali memberikan pengarahan, karena para guru dapat menjabarkan program-program innstitusi dan melaksanakan dengan, para guru dapat mengatasi persoalan secara mandiri dan memutuskan solusi yang terbaik untuk kepentingan keberhasilan pencapaian tujuan pendidikan".

Kendala suatu masalah dalam pembelajaran, terutama yang dialami oleh guru-guru bidang studi. Kendala tersebut bisa datang dari guru itu sendiri, dari peserta didik, lingkungan keluarga, atau karena faktor fasilitas, dan termasuk internal sekolah. Kepala sekolah dalam menerapkan kedisiplinan kepada guru yang kurang disiplin yaitu dengan cara mengatur administrasi kelas dan memberlakukan peraturan-peraturan tepat waktu baik dari segi kehadiran maupun ketepatan jadwal mengajar. Menurut Wikipedia (Yamin dan Maisah 2009:48) "disiplin merupakan bentuk pelatihan yang menghasilkan suatu karakter atau perilaku khusus yang menghasilkan perkembangan moral, fisik, dan mental untuk tujuan tertentu". Dalam meningkatkan kedisiplinan guru, kepala sekolah menerapkan gaya intruktif. Kendala lain yang dihadapi kepala sekolah dalam meningkat kinerja guru adalah motivasi. Menurut Mulyasa (2013 [3]:195) "Motivasi adalah tenaga pendorong atau penarik yang menyebabkan adanya perilaku seseorang ke arah suatu tujuan tertentu. Motivasi berkaitan dengan 
apa yang diinginkan manusia (tujuan), mengapa ia mengingin-kan hal tersebut (motif), dan bagaimana ia mencapai tujuan tersebut (proses)". Selanjutnya, kendala dalam meningkatkan tanggung jawab guru dengan mengatur pembagian tugas mengajar. Pembagian tugas tersebut harus adil dan merata sesuai dengan bidang keahliannya masing-masing. Guru adalah orang yang harus bertanggung jawab terhadap pendidikan murid-murid, baik secara individual ataupun secara klasikal, baik di sekolah maupun di luar sekolah, Supardi (2013:92) yaitu: Guru yang bertanggung jawab adalah guru yang mengetahui, memahami nilai-nilai, norma-norma (kesusilaan, kesopanan, moral, sosial, maupun keagamaan) dan selalu berusaha untuk menyesuaikan segala tindaktanduk dan perilakunya sesuai dengan nilai dan norma-norma tersebut. Guru bertanggung jawab atas segala tindakannya kepada stakeholder pendidikan maupun kepada Tuhan Yang Maha Esa dalam kegiatan pembelajaran yang dilakukan di sekolah (di kelas atau di luar kelas).

\section{KESIMPULAN DAN SARAN}

Dari temuan penelitian di atas, maka dapat diberi beberapa kesimpulan, yaitu: Gaya kepemimpinan kepala sekolah dalam meningkatkan disiplin guru adalah dengan menggunakan gaya kepemimpinan otoriter dan demokratis yang melihat ketepatan waktu untuk memasuki kelas sesuai dengan jadwal yang telah ditetapkan sekolah.

Gaya kepemimpinan kepala sekolah dalam meningkatkan motivasi kerja guru pada SMP Fullday Al-Muhajirin Purwakarta lebih cenderung menggunakan gaya kepemimpinan demokratis yaitu dengan memberikan kesempatan kepada guru-guru untuk melanjutkan studi banding ke sekolah dan memberikan kesempatan dalam menindak lanjuti keluhan dan harapan guru. Gaya kepemimpinan kepala sekolah untuk meningkatkan tanggungjawab guru dalam melaksanakan proses pembelajaran adalah dengan menerapkan gaya kepemimpinan demokratis. Kendalakendala yang dihadapi kepala sekolah dalam meningkatkan kinerja guru yaitu masih ada guru yang kurang siap dalam mengajar. Masih banyak guru-guru yang belum mengikuti pelatihan-pelatihan. Di samping itu, terdapat kurangnya disiplin guru, motivasi kerja dan tanggung jawab guru dalam pembelajaran, sehingga kepala sekolah akan menerapkan bermacam-macam jenis gaya kepemimpinan.

Dari uraian kesimpulan di atas, maka saran penulis ialah kepada kepala sekolah agar sesering mungkin menggunakan gaya kepemimpinan demokratis, terutama dalam pembagian tugas mengajar guru secara adil dan mengikutsertakan 
guru-guru dalam berbagai kegiatan seperti: training, seminar, MGMP. Kepala sekolah, sebaiknya jangan terlalu sering menggunakan gaya kepemimpinan otoriter, karena dikhawatir akan berdampak pada: (1) guru semakin malas dan bosan dalam melaksanakan tugas mengajar, (2) tanggung jawab guru dapat terabaikan, dan (3) wibawa kepala sekolah sebagai pimpinan menurun atau hilang.

Kepada kepala sekolah untuk terus berupaya meningkatkan kinerja guru dengan memberikan penghargaan kepada guru yang berprestasi, memberikan perhatian baik dari segi materi maupun non materi, melibatkan guru-guru dalan menyusun program sekolah, mendengar-kan ide-ide guru serta memberi rasa aman untuk guru-guru sehingga guru-guru merasa nyaman dan memiliki terhadap peningkatan sekolah. kepala sekolah bersamasama dengan Dinas Pendidikan terkait, pengawas dan stakeholders lainnya, diharapkan dapat menyediakan sarana dan prasarana yang memadai dan dibutuhkan oleh guru dalam menunjang pembelajaran pada SMP Fullday Al-Muhajirin Purwakarta. Kepala sekolah dalam meningkatkan kinerja guru, hendaknya menjadi kepala sekolah yang profesional, karena dengan bermacam-macam gaya kepemimpinan kepala sekolah yang diterapkannya.
Program supervisi pengajaran di SMP Fullday Al-Muhajirin Purwakarta disusun berorientasi pada bimbingan terhadap tugastugas guru, seperti penyusunan program pengajaran, penyiapan perangkat pembelajaran (Satuan acuan pelajaran, rencana pembelajaran, alat evaluasi, penyiapan media pembelajaran dan lain-lain). Hal ini disusun melalui musyawarah antara kepala sekolah, wakil kepala sekolah, ketua pengajaran, ketua program keahlian dan guru senior.

\section{Pelaksanaan} supervisi pengajaran mengikuti tahapantahapan; tahap perencanaan awal, pelaksanaan observasi, dan tahap akhir (diskusi balikan). Program supervisi pengajaran yang dilaksanakan oleh kepala sekolah sudah berjalan, namun semua guru yang direncanakan untuk disupervisi belum terlaksana.

Teknik-teknik Supervisi Pengajaran yang digunakan oleh kepala sekolah adalah: 1) Teknik supervisi individu dengan melakukan; (a) kunjungan kelas, (b) Mengadakan observasi kelas (observation visits), (c) Membimbing guru-guru tentang cara-cara mempelajari pribadi siswa dan atau mengatasi problema yang dialami siswa, (d) Membimbing guruguru dalam hal-hal yang berhubungan dengan pelaksanaan kurikulum sekolah. 2) Teknik kelompok dengan kegiatan: (a) Mengadakan pertemuan atau rapat 
(meetings) secara priodik. (b) Mengadakan diskusi kelompok (group discussions), (c) Mengadakan penataran-penataran (inservicetraining). 3) Supervisi Klinis yaitu dengan kegiatan: Tahap perencanaan awal, Tahap pelaksanaan observasi, dan Tahap akhir (diskusi balikan).

Tindak Lanjut hasil supervisi Kepala Sekolah adalah melakukan pembinaan berdasarkan catatancatatan hasil kunjungan kelas terhadap guru setiap tahun, dan membuat program pembinaan guru pada tahun berikutnya.

Kesempatan untuk ikut secara aktif dalam kegiatan musyawarah guru mata pelajaran (MGMP). Pelatihan-pelatihan baik yang dilakukan oleh pemerintah daerah maupun pemerintah pusat atau instansi lainnya.

Hambatan-hambatan dalam Pelaksanaan Supervisi yang ditemui Oleh Kepala Sekolah adalah: (a) Rendahnya kompetensi sebagian supervisor yang ditunjuk, (b) Adanya kegiatan di luar jadwal supervisi yang tidak direncanakan, dan (c) Sulit Merubah Kebiasaan lama. Dalam hal lain seperti hubungan komunikasi antara kepala Sekolah dan guru kadang-kadang terjadi sedikit otoriter.

\section{DAFTAR PUSTAKA}

Arikunto, Suharsimi, 2004. DasarDasar Supervisi. Jakarta: PT Rineka Cipta.
Danim, Sudarwan. 2012. Visi Baru Manajemen Sekolah. Jakarta: PT. Bumi Aksara.

Engkoswara dan Kamariah, Aan. 2011. Administrasi Pendidikan. Bandung: Alfabeta.

Fattah, 2009. Konsep Manajemen Berbasis Sekolah (MBS) dan Dewan Sekolah. Bandung: Pustakan Bani Quraisy.

Kunandar. 2009. Guru Profesional: Implementasi Kurikulum Tingkat Satuan Pendidikan (KTSP) dan Sukses dalam Setifikasi guru. Jakarta: Rajawali Pers.

Mukhtar dan Iskandar. 2009. Orientasi Baru Supervisi Pendidikan. Jakarta: Gaung Persada.

Mulyasa, E. 2013. Implementasi Kurikulum Tingkat Satauan Pendidikan: Kemandirian Guru dan Kepala Sekolah. Jakarta: PT. Bumi Aksara.

Mulyasa, E. 2013. Manajemen dan Kepemimpinan Kepala Sekolah. Jakarta: PT. Bumi Aksara.

Mulyasa, E. 2013. Menjadi Guru Profesional: Menciptakan Pembelajaran Kreatif dan Menyenangkan. Bandung: Remaja Rosdakarya.

Purwanto, M. Ngalim, 2005. Administrasi dan Supervisi Pendidikan. Bandung: Remaja Rosdakarya.

Rusman. 2009. Manajemen Kurikulum. Jakarta: Rajawali Pers.

Sagala, Syaiful, 2010. Supervisi Pembelajaran. Bandung: Alfabeta. 
Sahertian, Piet. A, 2008. Konsep Dasar dan Teknik Supervisi Pendidikan: dalam Rangka Pengembangan Sumber Daya Manusia. Jakarta: Rineka Cipta.

Supardi. (2013). Sekolah Efektif: Konsep Dasar dan Praktiknya. Jakarta: Rajawali Pers.

Undang-Undang Permendiknas Nomor 13 tahun 2007, tentang Guru dan Dosen. Gaung Persada.

Usman, Nasir. 2012. Manajemen Mutu Kinerja Guru: Konsep, Teori dan Model. Bandung: Citapustaka Media Perintis.

Wahjosumidjo. 2011. Kepemimpinan Kepala Sekolah: Tinjauan Teoritik dan Permasalahannya. Jakarta: Rajawali Pers.

Wahyudi, 2009. Kepemimpinan Kepala Sekolah. Bandung: Alfabeta.

Wahyudi. 2012. Kepemimpinan Kepala Sekolah dalam Organisasi Pembelajaran. Bandung: Alfabeta.

Yamin, Martinis. dan Maisah. 2009. Manajemen Pembelajaran Kelas: Strategi Meningkatkan Mutu Pembelajaran. Jakarta: Gaung Persada. 